\title{
Özçekim (Selfie) Fotoğrafları Sosyal Ağlarda Paylaşma ve Paylaşmama Nedenleri
}

\author{
Kadriye Uzun (Dr. Öğr. Üyesi) \\ Sakarya Üniversitesi İletişim Fakültesi \\ kadriyeuzun@sakarya.edu.tr \\ Orcid: 0000-0002-2832-2429 \\ Dilek Melike Uluçay (Dr. Öğr. Üyesi) \\ Yaşar Üniversitesi İletişim Fakültesi \\ melike.taner@yasar.edu.tr \\ Orcid: 0000-0001-8112-3229
}

Başvuru Tarihi: 23.11.2018

Yayına Kabul Tarihi: 18.04.2019

Yayınlanma Tarihi: 22.07.2019

DOI: 10.17680/erciyesiletisim.487073

Uzun, K. ve Uluçay, D. M. (2019). Özçekim (Selfıe) Fotoğrafları Sosyal Ağlarda Paylaşma ve Paylaşmama Nedenleri. Erciyes İletişim Dergisi, 6 (2), 1121-1140.

DOI: $10.17680 /$ erciyesiletisim.487073

\section{Öz}

Bireylere kimlik inşası, öz kimliğin yönetimi ve sosyal ilişkilerin yönetilmesi konusunda yeni firsatlar sunan sosyal medya ortamlarında bireyler artık izleyici ya da topluluk karşısında imajlarını daha kolay vurgulayabilmekte ve özellikle fotoğraf üzerinden benlik sunumlarını güçlendirebilmektedirler. Özçekim bu anlamda bir çeşit iletişim aracı olarak değerlendirilmekte ve teknolojiyi daha sık ve etkili kullanan üniversite öğrencilerinin kişisel imaj sunuları için bir araç niteliği taşıyabilmektedir. $\mathrm{Bu}$ kapsamda, bu araştırmada Türkiye'de uzaktan öğrenim gören öğrencilerin özçekim yapma ve bu çekimleri sosyal medyada paylaşma eğilimlerini ve nedenlerini ortaya çıkarmak amaçlanmıştır. Bunun yanısıra araştırma, özçekim yapmayan ya da yapmasına rağmen herhangi bir sosyal paylaşım ağında paylașmayan uzaktan öğrenenlerin düşüncelerini de ortaya koymayı amaçlamaktadır. Bu amaçlarla araştırmanın örneklemini Anadolu Üniversitesi Açıöğretim Fakültesi'nde öğrenim gören ve çalışmaya gönüllü katılan 3112 üniversite öğrencisi oluşturmuştur. Çalışmada veri toplama aracı olarak 3 bölümden oluşan bir anket formu kullanılmıștır. Anket formunda katılımcıların demografik bilgilerini, özçekim yapma ve bunu sosyal ağlarda paylaşma nedenlerini belirleme amaçlı çoktan seçmeli sorular yer alırken; kullanıcıların özçekim yapmama nedenlerini belirlemede açık uçlu soruya yer verilmiştir. Nicel ve nitel yöntemlerin birlikte işe koşulduğu araştırmada nicel verilerin analizinde tanımlayıcı istatistiklerden faydalanılmıştır. Nitel veriler betimsel analizle yorumlanarak kategoriler haline getirilmiştir. Bu bağlamda elde edilen verilere göre kullanıcıların en fazla özçekim yapma nedeni farklı yüz ifadeleriyle kendini göstermek ve böylece eğlenmek; özçekim yapmama nedenleri ise sahip olunan imajı koruma, izlenimleri inceleme /başkalarını nasıl gördüğü, sistemi eleştirme, toplumsal ahlaka aykırı bulma olarak gruplandırılmıştır.

Anahtar Kelimeler: Özçekim, Benlik Sunumu, Sosyal Ağlar, Sanal İletişim. 


\title{
The Reasons of Sharing or Not Sharing Selfie
}

\author{
Kadriye Uzun (Dr. Öğr. Üyesi) \\ Sakarya Üniversitesi İletişim Fakültesi \\ kadriyeuzun@sakarya.edu.tr \\ Orcid: 0000-0002-2832-2429 \\ Dilek Melike Uluçay (Dr. Öğr. Üyesi) \\ Yaşar Üniversitesi İletişim Fakültesi \\ melike.taner@yasar.edu.tr \\ Orcid: 0000-0001-8112-3229
}

Date Received: 23.11.2018

Date Accepted: 18.04 .2019

Date Published: 22.07.2019

DOI: 10.17680/erciyesiletisim.487073

\begin{abstract}
Individuals are able to strengthen their self-presentations and self-images infront of the communities and publics via social media that provides new opportunities for identity construction, image and social relations management. Selfie is considered as a communication tool, especially for university students who use technology more often and efficiently. In this scope, the purpose of this study is to reveal the reasons of taking and sharing selfie of distance university learners in Turkey. Besides, the study aims to uncover the reasons of not taking selfie or not sharing it on social media. The sample of the study includes 3112 distant university students enrolled in Anadolu University. A questionnaire form which consists of 3 categories is used to collect the data. In the form, there are questions asking the participants demographic information, and there are multiple choice questions asking the reasons of taking selfies and sharing them on social media. Moreover, there are open ended questions that ask the reasons of not taking and sharing selfies. Both qualitative and quantiative methods are conducted in the study. For the analysis, descriptive statistics are applied for quantitative part. On the other hand, content analysis is applied to reveal the results of he qualitative part. The results of the study show that the most common reason of taking selfie is reflecting self image with different facial expressions and having fun. In addition, the most common reasons of not taking and sharing selfie are protecting self-image, analyzing impressions of others, criticism of the system and obeying ethics of the society.
\end{abstract}

Keywords: Selfie, Self-Presentation, Social Networks, Virtual Communication. 


\section{Giriş}

Sosyal ağ siteleri (SNSs) kullanıcıların birbirleriyle ilişki ve etkileşim kurmasını sağlayan sanal platformlardır (Cheung ve diğerleri, 2011, 1337; Murray ve Waller, 2007, 56). Sosyal ağ siteleri sayesinde kullanıcılar sosyal ilişkiler geliştirebilirler (Alloway ve diğerleri, 2013, 11). Nadkarni ve Hofmann'ın $(2012,16)$ çalışmasına göre, sosyal ă̆ araçlarından olan sosyal medya kullanımı bireyin iki temel ihtiyacını karşılamaktadır; bu ihtiyaçlar aidiyet ve benlik sunumudur. Bu bağlamda, sosyal ağlar bireye kimlik inșaası, öz kimliğinin yönetimi ve sosyal ilișkilerini yönetmesi konusunda yeni firsatlar sunmaktadır (Mascheroni ve diğerleri, 2015,1; Ramírez ve Palu-ay, 2015). Özellikle fotoğraf üzerinden iletişim benlik sunumunu güçlendirmektedir. Sorokowska ve arkadaşları $(2016,119)$ çalışmalarında, sosyal ağlar aracılığı ile benlik sunumunun, özçekim (selfie) olarak isimlendirilen, kişinin şahsına ait fotoğrafları Facebook, YouTube, Twitter ve Instagram gibi sosyal medya mecralarında paylaşım alışkanlığını tetiklediğini belirtmişlerdir. Buna ek olarak Lobinger ve Brantner (2015, 1849), kişinin kendine ait fotoğrafları sosyal ağlar üzerinde paylaşmasının, benlik sunumunun detaylı olarak görselleștirilmesi ve kişiye özel unsurların öne çıkarılması işlevlerini yerine getirdiğini ileri sürmüşlerdir.

Alanyazın incelendiğinde, çevirim içi benlik sunumu, profil fotoğrafları ya da çevirim içi fotoğraf paylaşım alışkanlıklarını konu alan çalışmalara rastlanmıştır (Sorokowska ve diğerleri, 2016, 123-124). Sosyal medya kullanım alışkanlıklarını konu olan çalışmaların sayısında önemli bir artış yaşanmasına rağmen, özçekim davranışları ile ilgili deneysel ve araştırmaya dönük çalışmaların yeterli doygunluğa ulaşmadığı görülmektedir (Barry ve diğerleri 2015, 1). Alanyazında var olan özçekim araştırmaları çoğunlukla narsizm ve kendini gerçekleştirme ile özçekim davranışı arasındaki ilişkiyi sorgulamaktadır. Özçekim yapma ve paylaşma davranışı ve kişilerin konuyla ilgili eğilimlerini araştıran çalışmaların sayısı ise sınırlıdır (Alblooshi, 2015; Barry, Doucette ve diğerleri, 2015; Sorokowski ve diğerleri, 2015; Weiser, 2015; Wickel, 2015). Özellikle teknolojiyi daha sık ve etkili kullanan üniversite öğrencileri, sosyal ağları, sosyal çevrelerinin önceliklendirdiği kişisel imaj sunuları için tercih ederek sıklıkla özçekim paylaşımları yapmaktadırlar. (Pempek, ve diğerleri, 2009; Ramírez ve Palu-ay, 2015). Bu bağlamda özellikle Türkiye'de uzaktan öğrenim gören üniversite öğrencilerinin teknoloji, internet ve mobil platformları daha yoğun kullandıkları savından yola çıkarak, bu örneklem üzerinde özçekim davranış ve eğilimlerini incelemenin önemli olduğu düşünülmüştür. Bu kapsamda, bu araştırmada Türkiye'de uzaktan öğrenim gören öğrencilerin özçekim yapma ve bu çekimleri sosyal medyada paylaşma eğilimlerini ve nedenlerini ortaya çıkarmak amaçlanmıştır. Bunun yanısıra araştırma, özçekim yapmayan ya da yapmasına rağmen herhangi bir sosyal paylaşım ağında paylaşmayan uzaktan öğrenenlerin düşüncelerini de ortaya koymayı amaçlamaktadır. Bu çerçevede çalışmada aşağıdaki araştırma sorularına yanıt aranmıştır:

1. Uzaktan öğrenenlerin özçekim fotoğraflarını sosyal paylaşım ağlarında paylaşma eğilimleri nelerdir?

2. Uzaktan öğrenenlerin özçekim yapma eğilimleri demografik özelliklerine göre (cinsiyet, yaş ve medeni durum) farklılık göstermekte midir?

3. Özçekim yapmayan/paylaşmayan uzaktan öğrenenlerin, bu davranışlarının nedenleri nelerdir? 


\section{Özçekim (Selfie) Kavramı}

Oxford tarafından 2013 yılının kelimesi seçilen ve bir kişinin telefonunu ya da web kamerasını kullanarak kendi fotoğrafını (ya da kendinin de bulunduğu toplu grup fotoğrafını çekmesi ve daha sonra bunu sosyal medya sitelerinde paylaşması anlamına gelen özçekim (selfie), dünyada spordan sanata, iş çevrelerinden gündelik yaşama kadar birçok kişinin, MySpace, Facebook, Twitter, Tumblr, Instagram gibi çeşitli sosyal medya mecraları üzerinde paylaştıkları en popüler fotoğraflar haline gelmiştir (Fausing, 2013, 3).

Akıllı telefonlarla doğaçlama yaşanan bir anı hemen yakalamak ve sonrasında bunu sosyal medyada paylaşılabilmek artık daha kolay hale gelmiştir ve bu durum özçekim fotoğrafının, basılı fotoğraflardan daha samimi olmasını da sağlayabilmektedir (Peek, 2014). Özçekim fotoğrafları aynı zamanda bir çeşit iletişim aracı halini almıştır. Aynı zamanda bir fotoğrafın temsil niteliğinin kelimelerden daha güçlü olduğu savıyla, özçekim fotoğraflar kişinin benlik sunumunda kendisine güçlü bir kontrol olanağı sunmaktadır (Murphyaug, 2015). Bir diğer deyişle, yeni teknolojilerin kullanıcılarına, izleyici ya da topluluk karşısında imajlarını vurgulamalarına ve kendilerini ortaya çıkarmalarına izin verdiği söylenebilir (Becker ve Stamp, 2005, 244).

Internet çalışmalarının başladığı günden bu zamana kadar pek çok araştırmacı çevirimiçi yaratılan kimlikleri Goffman'ın (1959) benlik sunumu teorisi ve izlenim yönetimi kavramı ile ilişskilendirerek tartışmıştır. (Mascheroni, Vincent ve Jimenez, 2015, 2). Goffman'ın benlik sunumu kuramı, sanal ortamlara uyarlanarak yeniden güncellenmiştir (Becker ve Stamp, 2005). Bununla birlikte izlenim yönetimi kavramı yine Goffman (1959) tarafından, başkalarının birey üzerindeki izlenimlerini kontrol edebilme yetisi olarak tanımlanmıștır. Leary (1996) ise izlenim yönetiminin bireyler için temel işlevlerini bireylerarası etki, kişiliğini geliștirmek ve sürdürmek, olumlu duyguları düzenlemek olarak sıralamıştır.

Yeni teknolojiler kullanıcılarına, sosyal medya ortamlarında izleyici ya da topluluk karşısında imajlarını vurgulamalarına ve kendilerini ortaya çıkarmalarına izin vermektedir. Çevrimiçi ortamlarda, kendini sunum davranışları çevrimdışı ortamlar gibi normal ve yaygın bir nitelik kazanmaktadır (Kane, 2008, 5). İnsanların kendilerine bir aynadan bakarak kendi oto-portrelerini betimlemeleri, bir bakıma kişiyi diğerlerinden ayıran ve kendilerini tanımlamalarını sağlayan benzersiz bir hareket olarak nitelendirilmektedir (Fausing, 2013, 4).

İnsanlar genelde çevresindeki kişilerin kendisine yönelik izlenimlerini denetlemek ve kontrol etmek isterler (Martin ve diğerleri, 2000). Bireyin kendisi ile ilgili izlenimleri takip etmesi ve diğer bireyleri istediği yönde etkileme girişimlerinde bulunması doğal olmakla birlikte, sosyal etkileşime konu olan bu tarz davranışların incelemesi önem taşımaktadır (Leary ve Kowalski, 1990).

Özçekim fotoğraflar, önceki araştırmalara konu olmuş, ancak bu araştırmalar daha çok özçekim fotoğrafların narsizm veya kendini gerçekleştirme olgularıyla arasındaki ilişkiyi ortaya koymayı amaçlamıştır. Örneğin, Barry ve diğerleri $(2015,4)$ Instagram sosyal paylaşım mecrası üzerinde paylaşılan özçekim fotoğrafları inceleyerek, bu fotoğrafların narsizm ve kendini gerçekleştirme kavramları ile ilişkisini incelemiştir. Benzer şekilde Wickel $(2015,7)$ özçekim fotoğrafları paylaşma davranışının neden narsistik ve bencil davranışları arttırdığını incelemiștir. Ardından, Sorokowski 
ve diğerleri $(2015,124)$ benzer şekilde özçekim fotoğraf paylaşımı ve narsiszm arasındaki ilişkiyi irdelemiştir. Diğer bir çalışmada, Williams ve Marquez (2015, 1778) özçekim fotoğrafların sosyolojik analizini yaparak, bireylerin ırk ve toplumsal cinsiyete dair kimlik tüketimi ve üretimi özçekim fotoğrafları bir araç olarak kullanarak nasıl gerçekleştirdiğini açıklayan bir çalışma gerçekleştirmiştir. Diğer taraftan, Alblooshi $(2015,18-19)$ kendini gerçekleştirme seviyesi ve özçekim fotoğraf paylaşım sıklığı arasındaki ilişkiyi incelemiştir. Lobinger ve Brantner $(2015,1850)$ ise, kullanıcıların kendilerine ait fotoğrafların ve özçekim fotoğrafların ne ölçüde gerçeği yansıttığını incelemişlerdir. Son olarak Weiser (2015, 479), 1204 kişinin yer aldığı çalışmada özçekim fotoğraf paylaşımı sıklığı ve narsistik davranış arasında yüksek seviyede ilişki olduğunu ortaya çıkarmıştır.

Gerçekleștirilen çalışma, önceki araştırmalardan farklı olarak, özellikle teknoloji ve internet kullanımının daha yaygın olduğu varsayılan, Türkiye'deki uzaktan öğrenen üniversite öğrencilerinin özçekim fotoğrafların sosyal ağlar üzerinde paylaşım eğilimlerini belirlemeyi ve paylaşım yapmayan katılımcıların bu davranışlarının nedenlerini ortaya çıkarmayı amaçlamıştır.

\section{Yöntem}

\section{Araştırma Deseni}

$\mathrm{Bu}$ araştırmanın amacı göz önünde bulundurularak, nicel ve nitel araştırma yöntemlerinden faydalanılmıştır. Nicel araştırma yönteminde araştırmacılar tarafından tasarlanan araştırma deseni ile çalışma örnekleminden elde edilen veriler evrenin genelinin tutum, kanaat, özellik ve davranışlarını genellemeyi amaçlamaktadır (Creswell, 2005). Bu çalışmada anket yoluyla toplanan veriler, özçekim yapma ve paylaşma eğilimlerini ortaya çıkararak, evrenin tamamına genellenmeyi amaçlamıştır. Diğer yandan, nitel araştırma ise insanların yaşam tarzlarını, öykülerini, davranışlarını, örgütsel yapıları ve toplumsal değişmeyi anlamaya dönük bilgi üretme süreçlerinden biridir (Strauss ve Corbin, 1990). $\mathrm{Bu}$ çalışmada, açık uçlu sorulara verilen cevapları, betimsel analiz yöntemiyle inceleyerek, katılımcıların özçekim yapmama ya da sosyal ağlarda paylaşmama nedenleri anlamaya çalışılmıştır.

\section{Evren ve Örneklem}

Araștırmanın örneklemini Türkiye'de uzaktan öğrenim gören 3112 üniversite öğrencisi oluşturmaktadır. Araştırmada örneklem belirlenirken rastlantısal örnekleme yönteminden faydalanılmıștır. 2015-2016 Güz akademik yılında Anadolu Üniversitesi Açıköğretim Fakültesi'nde öğrenim gören 688.616 öğrencinin tamamına Google forms aracılığı ile sistem üzerinden araştırma anketi ulaştırılmış ve 3112 öğrenci anket formunu doldurarak çalışmaya kendi isteğiyle katılmıştır. Konu ile ilgili alanyazın incelendiğinde internet ile ilgili çalışmalar için üniversite öğrencilerinin en uygun örneklem gruplarından biri olduğu anlaşılmaktadır. Üniversite öğrencilerinin internet ve sosyal medya araçlarını kullanım sıklığı ve yeni teknoloji araçlarını kullanım konusundaki becerilerinin yüksek olması sebebiyle internet ile ilișkili çalışmalarda uygun örneklem olarak değerlendirildiği düşünülmektedir (AmichaiHamburger ve Vinitzky, 2010; Charney ve Greenberg, 2002; Morahan-Martin ve Schumacher, 2000; Pornsakulvanich, Haridakis ve Rubin, 2008). Ek olarak, uzaktan öğrenim gören öğrencilerin birbirleri ve öğretim elemanları ile iletişimi, teknoloji ve internet aracılığı ile gerçekleştirdikleri düşünülürse, uzaktan öğrenenlerin özellikle 
interneti konu alan çalışmalar için uygun örneklem grubu olabileceği söylenebilir (Simonson, Smaldino, Albright ve Zvacek, 2012).

Bu çalışmada yer alan 3112 uzaktan öğrenenin 60\%'ı (n=1891) erkek, 40\%'ı(n=1221) kadındır. Katılımcıların 68\%'i (n=2126) medeni durumunu bekâr ve 32\%'si (n=986) evli olarak belirtmiştir. Çalışmaya katılan öğrencilerin büyük çoğunluğu (\%92) 1940 yaş aralığında değişmektedir. Detaylandırılmış yüzdeler sırasıyla şöyledir; 18 ve altı: $1 \%(n=31), 19$ ve 29 arası: $72 \%(n=2224), 30$ ve 40 arası: $20 \%(n=629), 41$ ve 50 arası: $6 \%(n=187), 50$ ve üzeri: $1 \%(n=41)$.

\section{Verilerin Toplanması}

Pek çok veri toplama yöntemi olmakla birlikte en yaygın veri toplama yöntemleri anket ve görüşmelerdir (Creswell, 2005). Bu çalışmada veri toplama aracı olarak 3 bölümden oluşan bir anket formu kullanılmıştır. Birinci bölüm, kullanıcıların demografik bilgilerini, ikinci bölüm katılımcıların özçekim fotoğraflarını sosyal medyaya ekleme sıklıkları, özçekim yapmak için harcadıkları süre, özçekim fotoğraflarında kimlere yer verdikleri, özçekim yapma ve sosyal ağlarda paylaşma nedenlerine ilişkin soruları içermektedir. Üçüncü bölüm ise, herhangi bir sosyal ağda özçekim fotoğraf paylaşımı yapmadığını belirten kullanıcıların paylaşım yapmama nedenlerini yazmalarının istendiği açık uçlu bir sorudan oluşmaktadır; anketin ikinci bölümünde hiç selfie paylaşımı yapmadığını belirten katılımcıların diğer bölümleri yanıtlamadan bu bölüme geçmeleri istenmiştir. Anket hazılandıktan sonra görünüş geçerliğinin (face validity) sağlanması için 3 uzmanın görüşlerine sunulmuştur. Uzman olurlarının ardından, ankete son hali verilmiş ve Üniversiteden gerekli izinler alınarak öğrencilerle sistem üzerinden Google forms aracılığı ile paylaşılmıştır. Veriler 2015-2016 akademik yılı Güz dönemi içerisinde toplanmıştır.

\section{Verilerin Analizi}

Araştırmadan elde edilen veriler SPSS programı ile analiz edilmiștir. Verilerin analizinde tanımlayıcı istatistiklerden faydalanılmıştır. Araştırmanın açık uçlu sorusu neticesinde elde edilen verilerin analizinde nitel veri analiz yöntemlerinden betimsel analiz işe koşulmuştur. Betimsel analiz, çeşitli veri toplama teknikleri ile elde edilmiş verilerin daha önceden belirlenmiş temalara göre özetlenmesi ve yorumlanmasını içeren bir nitel veri analiz türüdür. Bu analiz türünde araştırmacı görüştüğü ya da gözlemiş olduğu bireylerin görüşlerini çarpıcı bir biçimde yansıtabilmek amacıyla doğrudan alıntılara sık sık yer verebilmektedir. Bu analiz türünde temel amaç elde edilmiş olan bulguların okuyucuya özetlenmiş ve yorumlanmış bir biçimde sunulmasıdır (Yıldırım ve Şimşek, 2003, 224). Bu bağlamda, araştırmacılar, anketin açık uçlu sorusuna verilen cevapları bir tabloya dönüştürmüş, betimsel bilgiler bölümündeki tüm verileri satır satır okuyarak değerlendirmiş, karşılaştırmış, benzer olay ve durumları gruplandırarak temalar ve bunların altında katergoriler çıkartarak içerik analizi yapmışlardır. İçerik analizinde temalar ve alt kategoriler kodlama güvenirliğinin (inter-coder reliability) sağlanması amacıyla 2 araştırmacı tarafından kodlanmıştır. Kodlama güvenirliği 92\% olarak hesaplanmıştır. Araştırmacılar, görüş birliğinin sağlanamadığı maddeleri tartışarak bu maddelerde görüş birliğine ulaşmışlardır.

\section{Bulgular ve Tartışma}

Araştırmadan elde edilen bulgular üç başlık altında gruplara ayrılarak verilmiştir. Bu başlıklar şu şekildedir: 
1. Özçekim yapan uzaktan öğrenenlerin demografik özelliklere göre (cinsiyet, yaş ve medeni durum) incelenmesi

2. Uzaktan öğrenenlerin özçekim fotoğraflarını sosyal paylaşım ağlarında paylaşma eğilimleri:

a. Öğrenenlerin özçekim fotoğraflarını sosyal medyaya ekleme sıklıkları

b. Özçekim yapmak için harcadıkları süre

c. Özçekim fotoğraflarında kimlere yer verdikleri

d. Özçekim yapma ve sosyal ağlarda paylaşma nedenleri

3. Herhangi bir sosyal ağda özçekim paylaşımı yapmayan öğrenenlerin görüşleri

\section{1. Özçekim yapan uzaktan öğrenenlerin demografik özelliklere (cinsiyet, yaş ve medeni durum) göre incelenmesi:}

Araştırmaya katılan toplam 3112 kişi içinde, öğrenenlerin \%60’ı (n=1855) özçekim yaparak bu fotoğraflarını sosyal paylaşım ağlarında paylaştığını, \%40’ı (n=1257) ise özçekim fotoğraf paylaşımı yapmadığını belirtmiştir. Özçekim yaparak paylaşım yaptığını belirten 1855 katılımcının demografik bilgileri incelendiğinde, bu kişilerin \%55'inin (n=1014) erkek, \%45'inin (n=841) kadın öğrencilerden oluştuğu görülmektedir. Katılımcıların \%77'si $(n=1422)$ bekâr, \%23'ü (n=433) evlidir. Katılımcıların yaş dağılımları ise sıralandığı gibidir; 18 ve altı: 1\% (n=23), 19-29 arası: $80 \%(\mathrm{n}=1489), 30-40$ arası: $15 \%(\mathrm{n}=271), 41-49$ arası: $3 \%(\mathrm{n}=59), 50$ ve üzeri: $1 \%(n=13)$.

Ankete cevap veren katılımclların demografik bilgileri incelendiğinde büyük çoğunlukla 19-29 yaş aralığında olduğu görülmektedir. Moreau (2014) ve Bennett (2014), 18-34 yaş ve (Alblooshi, 2015) 18-24 yaş grubunun selfie trendi içinde olduğunu belirtmektedirler.

Sonuç olarak araştırmada, durum cinsiyet açısından irdelendiğinde, haftada 2 kez, günde $1 \mathrm{kez}$, günde $3 \mathrm{kez}$ ve daha fazla selfie çektiğini belirten kadınların sayısı ile erkeklerin sayısı arasında farklılık bulunmaktadır. Başka araştırmalarda da benzer sonuçlarla karşılaşılmıștır (Sorokowski vd., 2015; Katz ve Croker, 2015). Ruie ve Stefanone'nin (2013) yaptığı araștırma ile duruma daha farklı bakılmaktadır. Araștırmacılara göre, özsaygı ve özdeğerleri dış görünümlerine endeksli olan kadınlar, sosyal ağlarda daha çok fotoğraf paylaşmaktadır.

\section{Uzaktan öğrenenlerin özçekim fotoğraflarını sosyal paylaşım ağlarında paylaşma eğilimleri:}

\section{a. Katıımcıların özçekim fotoğraflarını sosyal medyaya ekleme sıkıkları:}

Anket formunda kullanıcılara özçekim fotoğraflarını sosyal medyaya hangi sıklıkla ekledikleri sorulmuştur. Buna göre toplam 1855 katılımcıdan 1065'i (\%57) ayda bir kez özçekim fotoğrafını sosyal medyaya eklediğini belirtmiştir. Haftada bir kez yükleyen kullanıcı sayısı ise 391 kişidir (\%21).

Barry ve diğerleri (2015), araştırmalarında katılımcı öğrencilerin neredeyse yarısının (\%46) hergün, üçte birinin (\%31) haftada bir ya da iki kez özçekim fotoğrafı paylaştıklarını ortaya çıkarmışlardır. Araştırmacıların diğer önemli tespiti ise, gün içinde paylaşılan fotoğraf sayısının 3 ile 20 arasında değiştiğidir. Katz ve Croker $(2015,1864)$ çalışmasının bulguları da bu araştırma ile benzer nitelik taşımaktadır. Katz ve Croker $(2015,1864)$, araştırmasına katılanlardan \%9'nun gün içinde, 30\% nun haftada bir kez, 17\% sinin ise son bir ay içinde fotoğraf paylaştıklarını belirlemiştir. 


\section{b. Katıımcıların özçekim yapmak için harcadıkları süre:}

Anketin bu bölümüne cevap veren toplam 1846 öğrenen bulunmaktadır. Erkek katılımcılardan 774'ü (\%77) ve kadın katılımcılarından 410’u (\%49) özçekim fotoğrafı çekmek için 1 dakika harcadıklarını belirtmişlerdir. Bununla birlikte çalışmada, özçekim yapmak için 18 yaş ve altı kişilerin (\%48) 5 dakika süre harcadığı ortaya çıkmıştır.

\section{c. Katıımcıları özçekim fotoğraflarında kimlere yer verdikleri:}

Anket formunun bu bölümünü 1855 katılımcı cevaplamıștır. Erkeklerin \%64,7'sinin ailesi; \%19,3'ünün sadece kendisi; \%8,8'inin sevgilisi veya eși; \%5,2'sinin arkadaşı özçekim fotoğraflarında yer almaktadır. Bu durum kadın öğrencilerde de değişmemekte ve \%64,7'si ailesine; \%17,9'u sadece kendisine; \%9,8'i sevgili veya eşine; \%6'sı arkadaşına fotoğrafta yer vermektedir. Bu durum, özçekim fotoğrafı hiç çekmeyen ya da çekmesine rağmen sosyal paylaşım ağlarında paylaşmayan kişilerin verdikleri cevaplarla benzer nitelik taşımaktadır. Bu şekilde cevap veren kullancıların özçekim fotoğraflarını nadiren çektikleri ya da başkaları tarafından bu fotoğrafların çekildiği ileri sürülmekte ve bunun da çoğunlukla aile bireyleriyle biraraya geldiklerinde gerçekleşen bir durum olduğu ifade edilmektedir. Özçekim fotoğrafında aile, arkadaş, eş ya da sevgili sadece kendilerinin bulunduklarını söyleyenlerin yanında araştırmada ortaya çıkan bir diğer durum ise, kullanıcıların selfie fotoğraflarında sahip oldukları evcil hayvanlarına yer vermeleridir.

Öğrencilerin özçekim fotoğrafları aileleri ile birlikte çekmeleri Türk toplumunun kollektivist doğası ile ilişkilendirilebilir. Hofstede'nin $(2001,2010)$ çalışmasına göre, bir toplumun kendini bireyci veya kollektivist olarak konumlandırması, bireyin kendi imajını "ben" ya da "biz" olarak ifade etmesiyle yansıtılmış olur. Hofstede'ye göre, Türkiye "biz" i daha çok önemseyen kendisini ait oldukları topluluk ya da gruplara göre tanımlayan kollektivist bir yapıya sahiptir. Diğer yandan, bireyci olarak nitelendirilen batılı toplumlarda konuyla ilgili yapılan çalışmalarda farklı sonuçlar ortya çıktığı görülmüştür.

\section{d. Katıımcıların özçekim yapma ve sosyal ağlarda paylaşma nedenleri:}

Kullanıcıların özçekim fotoğrafı çekme ve bunu sosyal ağlarda paylaşma nedenleri sorgulandığında, hem kadınlar hem de erkek kullanıcılar için benzer sonuçların ortaya çıktığı görülmektedir. Buna göre, erkek kullanıçların \%28,8'i; kadın kullanıcıların ise $\% 27,9$ 'u farklı yüz ifadeleriyle kendini göstermek ve böylece eğlenmek için özçekim fotoğraf çektiği ve bu fotoğrafları sosyal paylaşım ağlarında paylaştıkları belirlenmiştir. Kullanıcıların özçekim yapma ve paylaşma nedenleri sıralandığında elde edilen bilgiler şu şekildedir: Erkek kullanıcıların \%17,2'si gittiği mekânı göstermek; \% 15,2'si beraber olduğu kişiyi göstermek; \%13,0'ı mutlu anları hatırlamak; \%9,3 yeni saç şeklini, rengini, görünümünü göstermek için, \%8,2'si mutlu olduğunu göstermek; \%5,9 çevresinden kabul görmek; Kadın kullanıcıların ilk beș sıraya koydukları nedenler ise şu şekildedir: \%17,4'ü gittiği mekânı göstermek; \% 15,9'u beraber olduğu kişiyi göstermek; \%12,3'ü mutlu anları hatırlamak; \%8,8'si mutlu olduğunu göstermek; \%7,1 çevresinden kabul görmek için paylaşmaktadır.

Peek'e (2014) göre, özçekim belirli zamanlarda yaşananların ve hissedilen duyguların yansıtılmasının bir yoludur. Dijital çağın önemli bir parçası haline gelen selfie ile kullanıcılar, farklı görünümleri deneyimleyerek kimliklerini geliştirme yoluna gidebilmektedirler. Her ne kadar, özçekim tek başına, grupla ya da partnerle birlikte 
çekilen bir uygulama olsa da, genelde kişiler saç modelini, klyafetlerini, eğlenceli yüz ifadelerini göstermek için böyle bir eğilim içine girmektedirler. Alblooshi (2015), özçekim ekleyen kişilerin beğeni ya da pozitif yorum alınca kendilerini iyi hissettiklerini belirtmektedir. Araştırmacı buna ek olarak, kullanıcıların özçekim ekleme nedenlerinin yeni görünümlerini/stillerini göstermek ve ne yaptıklarını herkese bildirmek olduğunu ve çok az kişi vakit öldürmek için selfie eklediklerini ifade etmektedir (Alblooshi, 2015). Wickel (2015), özçekim anıları saklı tutmanın bir yolu olarak görüldügünü ve kişilerin kendileri hakkında iyi hissetmelerini sağladığını belirtmektedir.

\section{Herhangi Bir Sosyal Ağda Özçekim Fotoğraf Paylaşımı Yapmayan Katılımcıların Görüşleri}

Anket formu içerisinde yer alan sorulardan bir tanesi de özçekim fotoğrafı çekip herhangi bir sosyal paylaşım ağında paylaşmayı sevmeyenlere yönelik olmuştur. Anketin bu sorusu açı uçlu bırakılmış ve katılımcılardan özçekim fotoğrafını eklememe nedenlerini yazmaları istenmiştir. Ankete katılan ve \%30'u $(n=380)$ kadın; \%70'i (n=877) erkek olmak üzere toplam 1257 öğrenen, özçekim fotoğrafı paylaşmadığını belirtmiş ve bazıları paylaşmama nedenlerini ayrıntılı olarak anket formunda açıklamışlardır. Paylaşım yapmayan katılımcıların demografik bilgilerine bakılırsa bu kişilerin \%56'sının ( $n=704)$ bekâr; \%44'ünün (n=553) evli olduğu saptanmıştır. Katılımcıların yaşlarının dağılımının ise 18 ve altı \% 0,6 (n=8); 19-29 arası 58,5\% ( $\mathrm{n}=735) ; 30-40$ arası: $28,5 \%(\mathrm{n}=358) ; 41-50$ arası: $10,2 \%(\mathrm{n}=128) ; 50$ ve üstü \%2,2'dir ( $\mathrm{n}=28)$ şeklinde olduğu belirlenmiştir.

Betimsel analiz dört aşamada gerçekleşmektedir. Birinci aşamada araştırmacı, araştırma sorularından, araştırmanın kavramsal çerçevesinden ya da görüşme ve gözlemlerde yer alan boyutlardan hareket ederek veri analizi için bir çerçeve oluşturur. Böylece verilerin hangi temalar altında düzenleneceği ve sunulacağı belirlenmiş olur. Ardından, araştırmacı daha önce oluşturmuş olduğu çerçeveye dayalı olarak verileri okur ve düzenler. Bu süreçte verilerin anlamlı ve mantıklı bir biçimde bir araya getirilmesi önem taşımaktadır. Bu aşamadan sonra araştırmacı düzenlemiş olduğu verileri tanımlar. Bunun için gerekli yerlerde doğrudan alıntılara da başvurmak zorunda kalabilir. Bu sürecin sonunda araştırmacı tanımlamış olduğu bulguları açıklar, ilişkilendirir ve anlamlandırır. Araştırmacı bu aşamada ayrıca yapmış olduğu yorumları daha da güçlendirmek için bulgular arasındaki neden sonuç ilişkilerini açıklar ve ihtiyaç duyulması durumunda farklı olgular arasında karşılaştırma yapar (Yıldırım ve Şimşek, 2003,224).

$\mathrm{Bu}$ bilgiler doğrultusunda araştırmacılar, verilen cevapları, daha kolay analiz edebilmek için bir tabloya dönüştürmüş, betimsel bilgiler bölümündeki tüm verileri satır satır okuyarak değerlendirmiş, karşılaştırmış, benzer olay ve durumları gruplandırarak temalar ve bunların altında kategoriler çıkarmışlardır. Bu kapsamda verilen cevaplar iki başlık altında tema ve alt temalarla sınıflandırılmıştır: 
Tablo 1: Herhangi Bir Sosyal Ağda Özçekim Fotoğraf

Paylaşımı Yapmayan Katılımcıların Görüşleri

\begin{tabular}{|c|c|}
\hline \multicolumn{2}{|c|}{ A. Özçekim Fotoğrafını Hiç Paylaşmama } \\
\hline Teknik ve zamansal sebepler & $\begin{array}{l}\text { Sosyal medya hesabının olmaması } \\
\text { Telefonun yetersiz donanımda olması } \\
\text { Kullanmayı bilmeme } \\
\text { Zaman bulamama } \\
\text { Fotoğraf çekmeyi sevmeme }\end{array}$ \\
\hline $\begin{array}{l}\text { Kendini korumaya yönelik } \\
\text { kendini sunum davranışları/ } \\
\text { Kamunun dikkatinden kaçınma }\end{array}$ & $\begin{array}{l}\text { Kendisi gösterme intiyaç duymama } \\
\text { Kendini beğenmeme } \\
\text { Göz önünde olmak istememe } \\
\text { Karşı cinsten olanlar tarafından rahatsız edilmek istememe } \\
\text { Toplumsal çevreden tepki görmek } \\
\text { Asosyal olduğunu düşünme }\end{array}$ \\
\hline $\begin{array}{l}\text { Kendini tanıtmaya } \\
\text { yönelik kendini sunum } \\
\text { davranışları/ Örnek olma }\end{array}$ & $\begin{array}{l}\text { Ünlü olmadığını düşünme } \\
\text { Kolay ulaşılan biri olmak istememe } \\
\text { Mahremiyet - özel yaşam gizliliği tepkili olmaları } \\
\text { Kişisel bilgilerinin izinsiz kullanacağı endişesi } \\
\text { İnsanları yarışa ve kine yönlendirdiğine inanma } \\
\text { Gereksiz bulma }\end{array}$ \\
\hline Sistemi eleştirme & $\begin{array}{l}\text { Ticari amaçlı doğduğunu düşünme } \\
\text { Popüler kültür ürünü olarak nitelendirme } \\
\text { Batı kültürüne özenti olarak nitelendirme } \\
\text { Sistem tarafından kullanılmaya zorunlu bırakılma }\end{array}$ \\
\hline \multicolumn{2}{|l|}{ Toplumsal ahlaka aykırı bulma } \\
\hline \multicolumn{2}{|l|}{ Kültürel ve dini nedenler } \\
\hline \multicolumn{2}{|c|}{ B. Sadece Sınırı Özçekim Paylaşımında Bulunma } \\
\hline \multicolumn{2}{|c|}{ C. İzlenimleri İnceleme /Başkalarını Nasıl Görüyor? } \\
\hline
\end{tabular}

Araştırmanın bu aşamasında kullanıcılar tarafından verilen cevaplar doğrultusunda kullanıcılar üç gruba ayrılmıștır: (1) Fotoğraflarını hiçbir şekilde paylaşmayan katılımcılar (2) sadece sınırlı paylaşımda bulunan katılımcılar ve (3) diğerlerini izleyen katılımcılar- izlenimleri inceleme.

\section{A. Özçekim Fotoğrafını Hiç Paylaşmayan Katııımcılar:}

Uzaktan öğrenenler içinde özçekim fotoğrafını hiç paylaşmayan kullanıcıların bu davranışlarının nedenleri teması altında teknik ve zamansal sebepler, kendini korumaya yönelik kendini sunum davranışları-kamunun dikkatinden kaçınma ve kendini tanıtmaya yönelik kendini sunum davranışları-örnek olma alt temaları ortaya çıkmıștır. Rosenfeld ve diğerleri (1995) tarafından geliştirilen kendini sunum taktikleri kendini tanıtmaya yönelik, savunmaya yönelik ve korunmaya yönelik olarak üçlü bir ayrımda verilmiştir. Bu çalışmada temalar belirlenirken bu ayrımdan da yararlanılmıștır. Araştırmacılara göre kendini korumaya yönelik kendini sunum davranışları-kamunun dikkatinden kaçınma kişilerin eleştirilmekten kaçındığı için çok fazla göz önünde bulunmak istememeleri durumunda sergilediği; kendini tanıtmaya yönelik kendini sunum davranışları-örnek olma ise bireyin diğerlerine karşı dürüstlük, doğruluk, cömertlik gibi erdemlerini ön plana çıkardığı kendini sunum davranışlarıdır (Schutz, 1998; Wate, 2000).

Araştırmaya katılan ve özçekim fotoğrafını herhangi bir sosyal medyada paylaşmayanların yukarıda belirtilen nedenleri incelendiğinde, en fazla ifade edilen kategorilerin açımlanması doğru olacaktır. Örneğin kendini beğenmeme alt kategorisi sıklıkla yer alan paylaşmama nedeni olarak ortaya çıkmıştır. Kullanıcıların özellikle ön çekim ile yapılan fotoğraflarda bütün kusurlarını göstermesi nedeniyle 
çirkin çıktıklarını düşünmeleri, fiziksel olarak kendilerini kilolu görmeleri ve görüntülerinin diğer kullanıcılar üzerinde olumsuz izlenim yaratacağı endișesi gibi nedenler onların özçekim fotoğrafı eklememelerinde etken olmaktadır. Alt kategoriler içerisinde özçekim yapmayı gereksiz bulduklarını söyleyenlerin gerekçelerini, ülkede ve dünyada birçok sorun varken, özçekim fotoğraflarına zaman harcamanın anlamsız olarak açıkladıkları görülmüştür. Kullanıcıların fotoğraf eklememe nedenlerinden biri de diğer kullanıcıların bu davranışlarına tepkili olmalarıdır. Tepkilerinin nedenleri ise, diğer kullanıcıların özçekim ile yani yakın çekim ile çektikleri fotoğraflarında çirkin çıktıklarını düşünmeleri, sosyal medyanın insanı yalnızlaştırdığına inanmaları, herkesin yaptığı sıradan ve moda bir davranış olarak değerlendirmeleri ve sürekli selfie fotoğrafı eklenmesini anlamsız bulmalarıdır.

Çalışmada elde edilen diğer özçekim yapmama nedenleri ele alındığında kişisel bilgilerinin izinsiz kullanacağı endişesi, gereksiz bulma, kendisi göstermeye ihtiyaç duymama alt temasına örnek olarak bir kullanıcının, "Özçekimin anlamı "Ben herkes bana baksın" diye bağırmak gibi geliyor. Oysa İnançlarım benliği öne çıkarmaya müsaade etmiyor. Insanların beni sadece sosyal medyadan takip edip, benim hakkımda bilgi sahibi olmaları rahatsızlık verici. Önyargılı bir durum. Yakın bir arkadaşınızı arayıp sormak yerine sosyal medyadan fotoğraflarla takip etmek, sanal bir hayattan «Merhaba» demek gibi bir şey. Ayrıca manzaranın veya olayın tadını çıkarmak varken neden sürekli fotoğraf çekinip belgeleyeyim ki? Kime neyi kanıtlıyorum? Insanları gereksiz bir girdaba çekiyor bu durum. Kendi hayatınızı hiç tanımadığınız insanların gözü önüne seriyorsunuz. Üstelik bilgilerinizin ne kadar güvensiz bir ortamda korunduğu ortada. Resimleriniz, izinsiz bir şekilde reklam amaçlı kullanılabiliyor tabi popülerseniz." açıklamaları vurgulayıcıdır.

Diğer nedenlere bakıldığında bir kullancının, "Özçekim yanımda birileri olmadığı zaman anıları sabitlemek için güzel ama onun haricinde zaman zayiatı bana göre. Gençlerimiz ülke sorunlarına ya da sosyal sorumluluk süreçlerine bu kadar çaba sarf etseler ülkede sorun kalmaz kısacası teknoloji güzel ama yanlış kullanıldığı zaman beynimizi uyuşturan bir afyondan öteye gitmez." ifadeleri özçekim paylaşmaya zamanı olmadığını ispatlar niteliktedir.

Çalışamaya katılanların özçekim paylaşmama nedeni olarak gösterdikleri ve toplumsal çevreden tepki görmek başlığı altında toplanan verilere bakıldığında faklı kişilerin şu ifadeleri çarpıcı bir nitelik taşımaktadır.

- Aile büyüklerinin hesabımda ekli olması beni etkiliyor.

- Evli olduğum için yanlış anlaşılabileceğini düşünüyorum.

- Şu anda çalışmıyorum fakat çalıştığım süre içinde iş yeri saygınlığımı zedeleyici bir davranış olduğunu düşünüyorum.

- Bulunduğum pozisyon gereği kurumsal kültürü taşıma zorunluluğu da bir başka nedenim

- Almış olduğum eğitim ve bulunduğum çevrede bu basit/alçaltıcı bir davranış olarak değerlendirilebiliyor.

Kendisi göstermeye ihtiyaç duymama nedeni olarak "Benim o halimi görmenin kimseye bir getirisi olmayacak" "O resmi paylaşacak bir neden bulamıyorum" ya da "Sosyal medya aracılığı ile yapay bir görünüm pazarladığımı düşünüyorum" 
ifadeleri kullanan katılımcılar yine özçekim yapmama gerekçesini kendilerine göre açıklamışlardır.

Sistemi eleştirme

Özçekim fotoğraflarını sosyal medyada paylaşmama nedenleri kapsamında yer alan diğer bir tema ise, kullanıcıların sisteme yani var olan düzene yönelik eleștirileridir. Bu kapsamda şu alt kategoriler bulgulanmıştır:

- Ticari amaçlı doğduğunu düşünmeleri (kar amaçlı bilerek yapılmış)

- Popüler kültür ürünü olması

- Batı kültürüne özenti

- Kişisel bilgilerin toplandığ bir alan yüz tarama sistemi

- Sistem tarafından kullanılmaya zorunlu bırakılma.

\section{Toplumsal ahlaka aykırı bulma}

Kullanıcılar konuyu ahlaki yönden de değerlendirmişler ve selfie fotoğrafi eklemeyi toplumun ahlakını ve birliğini bozan, toplumsal değerlerin kaybedilmesine neden olan bir süreç olarak yorumlamışlardır. Ayrıca ülkede üzüntü veren olaylar varken böyle bir davranış içine girmeyi doğru bulmadıklarını belirtmişlerdir. Bunun yanısıra, kendi kendine fotoğraf çekmek yerine bir başka kişiden fotoğraf çekmesini istemenin daha samimi olduğunu ve sosyal etkileşimi artırdığını söyleyen kullanıcılar da bulunmaktadır.

Kültürel ve dini nedenler

Araştırmada ortaya çıkan bir diğer sebep ise kültürel ve dini etkenlerdir. Kullanıcıların selfie fotoğrafı ekleyince nazar değeceğine inanmaları ve inandıkları dinin bu tarz davranışlara izin vermemesi selfie fotoğrafı eklememe nedeni olarak ileri sürülmüştür.

\section{B. Sadece sınırlı özçekim paylaşımında bulunan katılımcılar:}

Ankete katılan kullanıcılardan bazıları özçekim fotoğrafı paylaşımını eleştirmekle birlikte zaman zaman kendilerinin de paylaşımda bulunduklarını belirtmişlerdir. Özellikle aile, arkadaş gibi yakın çevreleriyle bir araya geldiklerinde, yani grup halinde iken ya da sadece fotoğrafın içinde kendilerinin olmadığı halde güzel bir manzarayı göstermek amacıyla fotoğraf ekleyen kullanıcılar bulunmaktadır. Çağın gerisinde kalmamak, kuşak çatışması yaşamamak adına da sınırlı sayıda paylaşımda bulunan kullanıcılar olduğu görülmektedir. Araştırmada çıkan bir diğer bulgu da, grup fotoğraflarında kişinin kendisi bizzat fotoğraf çekmemekle birlikte, diğer kișileri kırmamak adına grup özçekimlerinde yer aldığıdır. Bir kullanıcının "genellikle ailemle olan fotografları öz çekim yaparım başkalarının görmesi görmemesi beni ilgilendirmez kardeşlerimle anne ve babamla hatıra olsun diye o anı ölümsüzleştirmek için kullandığım öz çekimleri neden bir başkası görsün ki? Zaten biz de birbirimize watsapp yoluyla gönderiyoruz velevki paylaştım diyelim fotografları benim belirlediğim kişiler görür yine herkese açık paylaşımda bulunmam” şeklindeki ifadeleri bu durumu açlklar niteliktedir.

\section{C. İzlenimleri İnceleme /Başkalarını Nasıl Görüyor?:}

Özçekim yapmasına rağmen, bunu saklayan ve herhangi bir sosyal paylaşım ağına eklememe nedeni çalışmada diğer bir tema olarak belirlenmiştir. 
Kullanıcıların böyle bir davranışta bulunmalarının gerekçesi olarak, diğer kullanıcıların izlenimlerini inceleme sonrasında, onları değerlendirmeleri ve bir kanıya ulașmaları bulgulanmıștır. Burada böyle bir davranıș eğiliminde olan kişilerin, diğer kullanıcıların özçekim fotoğraflarını eklemeleri eleştirdiği ve onların özçekim fotoğrafı ekleme nedenlerini kendi görüşleri açısından açıklamaya çalıştıkları tespit edilmiştir.

Özçekim fotoğraflarını herhangi bir sosyal paylaşım ağına eklemeyen kişilerin, yapanları eleştirirken onların kendilerini bu şekilde herkese sergilemeleri "gösteriş meraklısı, görgüsüz, narsist kişilik özelliğinde, teşhirci, özgüven eksikliği yaşamaları, samimiyetsiz, olmadiklari gibi biri olarak kendilerini göstermeleri şeklinde yorumlanmakta ve yapmacık, asosyal abartılı, kendini beğenmeyen ya da kendini çok beğenenen insanların sergiledikleri bir davranış olarak açıklanmaktadır. Narsist nitelemesi yanlış bir vurgu olmamaktadır. Nitekim bazı araştırmalarda da özçekimin narsist bir davranış olduğu belirlenmiștir (Wickel, 2015; Weiser, 2015; Fox ve Rooney, 2015; Sorokowski ve diğerleri, 2015; Barry ve diğerleri, 2015; Burns, 2015).

Bu açıklamaların yanı sıra diğer kullanıcılar, kendi fotoğraflarını çekmek uğruna anın tadını çıkarmadıkları, herhangi bir işi olmayıp zamanın çok olmaları gibi nedenlerden eleştirilmiştir. Bazı kullanıcıların, hesaplarında ekli olan ve özçekim yapma konusunda eleştirdikleri kişileri zaman içinde arkadaş listesinden çıkardıkları tespit edilmiștir. Bir katılımcının șu ifadeleri bu verileri destekler niteliktedir.

"Sosyal paylaşım sitelerine fotoğraf eklemeyi sevmeyişim sadece selfie ile sınırl değil. Insanların, başka insanlara kendilerini olduklarından (aklıma ilk gelenler) daha güzel, daha mutlu, daha enerjik, daha vs vs gösterme çabalarını içeren tüm fotoğrafların eklenmesine mesafeliyim. Kısacası bunun, insanların samimiyetlerini öldürdüğünü düşünüyorum. Ayrıca, sosyal medya hesaplarına boy boy fotoğrafların konulmasını ve insanların daha fazla "like" alabilmek adına şekilden şekile girmelerini de içgüdüsel beğenilme gayeti çerçevesinde değerledirken, kendine güveni olan sağlam karaktere sahip kişilerin bu tarz şeylerle kendini tatmin etme gayreti içinde olmayacakalarını düşünüyorum. Sosyal medya hesabını ilk açtığında, ilk heves bir kaç kişisel fotoğraf yüklemiş birisi olarak bunun çok gereksiz olduğunu ve sosyal medyaya yüklenen fotoğraflar sayesinde insanların samimiyet derecelerinin daha fazla ortaya döküldüğ̈̈nü üzülerek görüyorum. Bu konunun üzerine uzun uzun konuşabiliriz, psikolojik ya da sosyolojik boyutlarını ele alabiliriz tabi ki... Daha fazla uzatmadan bir soru ile yazımı bitireyim: "Siz tüm 'arkadaș(!)'larınıza 'al sana fotoğrafımı vereyim, ara ara bak' diyor musunuz?". Bence hayır."

Başka bir kullanıcının "Gereksiz buluyorum. Fotoğraf atanları da kınıyor ve arkadaş listemden çıkarıyorum. Bence tüm bunların altında yatan şey insanın alt benliğinde yatan bastırılmış duygular" ifadelerinde o kişiyi arkadaşlıktan çıkarması özçekim fotoğraflarının sosyal ilişkileri belirleme konusundaki etkisini öne sürer niteliktedir.

Yine başka bir kullanıcı "Çekilen selfie ile anlatılmak istenenler ise; bugun pahallı bir restorantta yemek yiyorum, son model arabam var, dünyayı geziyorum, marjinalim vs listeyi sonsuza kadar götürebiliriz. Fakat bunlar insanı yozlaştırıyor ve yalnızlığa itiyor. Özçekim, selfie çekmek zorunda hissettikleri içinse anı yaşayamıyor sadece o anı sanal beyinlerde özelleştirmek istiyor. Hepimiz bitkisel hayatta yaşayan ve komadayken gördügümüz rüyaları gerçek zanneden bir toplum haline dönüştürülüyoruz. Sanal 
profiller ile yaşıyoruz." diyerek kendini sunum davranışları bağlamında izlenimleri incelemeye örnek teşkil etmektedir.

\section{a) Özçekim Fotoğraflarının Sosyal Medyaya Eklenme Sıklığı}

Uzaktan öğrenenlerin özçekim yapma ve paylaşma eğilimlerini ortaya koyarken araştırılan konulardan biri de özçekim fotoğraflarını sosyal medyaya ekleme sıklıkları olmuştur. Araștırmada kullanıcıların çoğunluğu ayda bir kez özçekim fotoğrafı yüklediğini belirtmekle birlikte, hafta bir kez yükleyen kullanıcı sayısı da dikkat çekmektedir. Barry ve diğerleri (2015), araştırmalarında katılımcı öğrencilerin neredeyse yarısının (\%46) hergün, üçte birinin (\%31) haftada bir ya da iki kez özçekim fotoğrafı paylaştıklarını ortaya çıkarmışlardır. Araştırmacıların diğer önemli tespiti ise, gün içinde paylaşılan fotoğraf sayısının 3 ile 20 arasında değiştiğidir. Katz ve Croker $(2015,1864)$ çalışmasının bulguları da bu araștırma ile benzer nitelik taşımaktadır. Katz ve Croker $(2015,1864)$, araştırmasına katılanlardan \%9'nun gün içinde, 30\% nun haftada bir kez, 17\% sinin ise son bir ay içinde fotoğraf paylaștıklarını belirlemiștir.

Araştırmada, durum cinsiyet açısından irdelendiğinde, haftada 2 kez, günde 1 kez, günde $3 \mathrm{kez}$ ve daha fazla selfie çektiğini belirten kadınların sayısı ile erkeklerin sayısı arasında farklılık bulunmaktadır. Başka araştırmalarda da benzer sonuçlarla karşılaşılmıştır. (Sorokowski vd., 2015; Katz ve Croker, 2015; Ruie ve Stefanone'nin (2013) yaptığı araștırma ile duruma daha farklı bakmaktadır. Araştırmacıya göre, özsaygı ve özdeğerleri dış görünümlerine endeksli olan kadınlar, sosyal ağlarda daha çok fotoğraf paylaşmaktadır.

\section{b) Özçekim Fotoğraflarında Yer Verilen Kişiler}

Araştırmaya katılanların selfie fotoğraflarında ilk olarak ailelerine, daha sonra arkadașlarına ya da partnerlerine yer verdikleri görülmektedir. Bunun yanısıra evcil hayvanıyla selfie çekenler de bulunmaktadır. Öğrencilerin özçekim fotoğrafları aileleri ile birlikte çekmeleri Türk toplumunun kollektivist doğası ile ilişkilendirilebilir. Hofstede'nin $(2001,2010)$ çalışmasına göre, bir toplumun kendini bireyci veya kollektivist olarak konumlandırması, bireyin kendi imajını "ben" ya da "biz" olarak ifade etmesiyle yansitılmış olur. Hofstede'ye göre, Türkiye "biz" i daha çok önemseyen kendisini ait oldukları toplulyk ya da gruplara göre tanımlayın kollektivist bir yapıya sahiptir. Diğer yandan, bireyci olarak nitelendirilen batılı toplumlarda konuyla ilgili yapılan çalışmalarda farklı sonuçlar ortya çıktığı görülmüştür.

\section{c) Öğrenenlerin Selfie Fotoğrafı Paylaşma Nedenleri}

İlgili çalışmada ortaya çıkan veriler ışığında özçekim yapmak için çok farklı sebepler bulunmaktadır. Araştırmaya katılanların genelde farklı yüz ifadeleriyle kendini göstermek ve böylece eğlenmek için özçekim yaptığı ve bu fotoğrafları sosyal paylaşım ağlarında paylaştıkları belirlenmiștir. Bununla birlikte gittiği mekânı göstermek; beraber olduğu kişiyi göstermek; mutlu anları hatırlamak; yeni saç şeklini, rengini, görünümünü göstermek mutlu olduğunu göstermek, çevresinden kabul görmek için selfie fotoğraflarını paylaşmaktadırlar.

Peek'e (2014) göre, özçekim belirli zamanlarda yaşananların ve hissedilen duyguların yansıtılmasının bir yoludur. Dijital çağın önemli bir parçası haline gelen selfie ile kullanıcılar, farklı görünümleri deneyimleyerek kimliklerini geliştirme yoluna gidebilmektedirler. Hernekadar, özçekim tek başına, grupla ya da partnerle birlikte 
çekilen bir uygulama olsa da, genelde kişiler saç modelini, klyafetlerini, eğlenceli yüz ifadelerini göstermek için böyle bir eğilim içine girmektedirler. Alblooshi (2015), özçekim ekleyen kişilerin beğeni ya da pozitif yorum alınca kendilerini iyi hissettiklerini belirtmektedir. Araştırmacı buna ek olarak, kullanıcıların özçekim ekleme nedenlerinin yeni görünümlerini/stillerini göstermek ve ne yaptıklarını herkese bildirmek olduğunu ve çok az kişi vakit öldürmek için selfie eklediklerini ifade etmektedir (Alblooshi, 2015). Wickel (2015), özçekim anıları saklı tutmanın bir yolu olarak görüldügünü ve kişilerin kendileri hakkında iyi hissetmelerini sağladığını belirtmektedir.

Araștırmanın iki bölümden oluştuğu ve ikinci bölümün özçekim yapmayan ya da yapmasınarağmensosyal paylaşımağlarındapaylaşmayanöğrencilerindüşüncelerine yer verildiği yukarıda belirtilmişti. Sonuçlar değerlendirildiğinde kullanıcıların sahip oldukları imajları korumak için, diğer kullanıcıların izlenimlerini incelemeleri ve sonrasında onları eleştirmeleri yani diğer kullanıcıların davranışlarına karşı tepki vermek için ya da özçekimi güvenli bulmamaları, toplumun ahlakını ve birliğini bozduğunu düşünmeleri, ayrıca kültürel ve dini gibi nedenlerle özçekime olumlu bakmadıkları belirlenmiştir.

Öğrencilerin bu davranışı yine kendini sunum davranışları kapsamında yer alan kendini korumaya yönelik davranışlar kapsamında değerlendirilebilir. Kendini korumaya yönelik kendini sunum davranışları insanların olumsuz izlenim vermekten kaçınarak kötü görünmemek için çabaları, korumaya yönelik kendini sunum davranışlarıdır. Bu tarz davranış içerisinde bulunan kişinin arzuladığı bir kimlik olmamakla birlikte, sahip olduğu sosyal kimliğin zarar görmesinden kaçındığı bilinmektedir. Kamunun dikkatinden kaçınma, kendin hakkında az bilgi verme, kendini tanımlarken dikkatli olma, sosyal etkileșimi en aza indirme, sessiz kalma bu bağlamda yer alan davranışlarıdır (Schutz, 1998).

Araștırmaya katılanların verdikleri cevaplar doğrultusunda diğer kullanıcılar gösteriş meraklısı, görgüsüz, teşhirci, özgüveni eksik, samimiyetsiz, olmadıkları gibi kendilerini göstermeleri ve beğenilme arzusunda olmaları ya da narsist gibi kişilik özellikleriyle nitelendirilmişlerdir. Narsist nitelemesi yanlış bir vurgu olmamaktadır. Nitekim bazı araştırmalarda da özçekimin narsist bir davranıș olduğu belirlenmiștir (Wickel, 2015; Weiser, 2015; Fox ve Rooney, 2015; Sorokowski ve diğerleri, 2015; Barry ve diğerleri, 2015; Burns, 2015).

\section{Sonuç}

Postmodern dönemde kimliklerin belirsizleşmesi hatta parçalanması söz konusu olabilmekte ve bu durum kişileri kimlik arayışına yönlendirmektedir. İnternet ortamı ve özellikle sosyal ağlar bireylere gündelik hayatındaki kimlikleri yeniden inşa edebilmevebunun yanısıratoplumsal kimliklerini deşekillendirmeyi vaatetmektedir. Bu anlamda özçekim, kimliğin sergilenmesinde ve böylece şekillenmesinde kolaylık sağlamaktadır. Kişinin cep telefonu ya da fotoğraf makinesini kendine çevirerek kendi portresini ölümsüzleştirdiği özçekim fotoğrafları sanal ortamın olmazsa olmaz paylaşımlarından biri haline gelmiş (Pösteki ve Velioğlu, 2014) ve özçekim temsilleriyle bireyler kendilerini en iyi șekilde başkalarının gözünde ve başkalarına karşı konumlandırabilme kolaylığına kavuşmuştur. Böylece insanlar başkalarının kendileri hakkında algısını da yönetebilme becerisi kazanmıştır. Bunun da sosyal medyada en büyük göstergesi takipçilerden alınan beğenidir. Beğeni sayısı kişinin 
popülerliğini de göstermektedir. Birey kendinden bağımsız olarak oluşturduğu temsiliyle kendisinden bağımsız bir selfie özbeni oluşturmaktadır. Özçekim bireylerden bağımsızlaşırken, bireyler kendi temsillerine daha bağımlı hale gelmektedirler (Akıner ve Küngerü, 2015).

$\mathrm{Bu}$ araştırmada teknoloji ile ilişkisinin daha ileri düzeyde olduğuna inanılan uzaktan öğrenenlerin özçekimde bulunma davranışlarının nedenleri sorgulanmak istenmiştir. Çalışma kapsamında oluşturulan ve iki aşamadan oluşan online ankete 3112 öğrenci katılmıştır. Bu katılımcılardan \%60’ı özçekim yaparak bu fotoğraflarını sosyal paylaşım ağlarında paylaşan ve\%40’ı özçekim fotoğraf paylaşımı yapmayanlardan oluşmuştur.

Özçekim yapan ve bunu herhangi bir sosyal medyada paylaşan kullanıcıların bu davranışlarının altında eğlenme güdüsü yatmaktadır. Popüler kültür içerisine hapsedilmiş kişilerin günlük rutin hayatlarının sıradanlığından kurtulmada özçekim fotoğrafları hızlıca yetişmektedir. Aslında eğlence amaçlı özçekim yapmak, yeni medyanın kullanıcılara sunduğu yeni bir boş zaman aktivitesi olarak da düşünülebilir. Çalışmada saptanan diğer özçekimde bulunma nedenleri olan gittiği mekânı göstermek, beraber olduğu kişiyi göstermek, mutlu anları hatırlamak, yeni saç şeklini, rengini, görünümünü göstermek, mutlu olduğunu göstermek eğilimleri ile Debord (2006,39), "görünen şey iyidir, iyi olan şey görünürdür” yani gösteri toplumu nitelemesini desteklemektedir. Bununla birlikte gösterilmek istenilen paylaşılmakta ve gösterilen ile sanal ortam içinde var olma, kendini gerçekleştirebilme anlayışı hüküm sürmektedir. Kendini özçekim ile göstermek isteyenlerin varlığının yanı sıra kullanıcıların bu davranışlarını görgüsüz, gösteriş meraklısı olarak gören, kendi fotoğraflarını çekmek uğruna anın tadını çıkarmadıkları, herhangi bir işi olmayıp zamanın çok olmaları gibi nedenlerden eleştiren bir kesim de bulunmaktadır.

Özçekim hakkında yapılan birçok çalışmada özçekim davranışlarının nedenlerinin sorgulandığı gözlenmiş, ancak özçekim yapmayan ya da özçekime karşı olumsuz düşünen kişilerin bu davranışlarının nedenlerine inilmemiştir. Bu nedenle çalışmanın diğer kısmını özçekimde bulunmayan ya da sınırlı olarak paylaşımda bulunan kullanıcıların görüşleri oluşturmaktadır. Bu bağlamda fotoğraflarını hiçbir şekilde paylaşmayan; sadece sınırlı paylaşımda bulunan ve diğerlerini izleyen katılımcılardan oluşan üç grup tespit edilmiştir. Fotoğraflarını hiçbir şekilde paylaşmayan katılımcılar, bu davranışlarının nedenleri için çok çeşitli sebepler ileri sürmüşlerdir. Örneğin toplumsal çevreden tepki görmek, ünlü olmadığını düşünmek, asosyal olduğunu düşünmek, insanları yarıșa ve kine yönlendirdiğine inanmak, zaman bulamamak, kolay ulaşılan biri olma algısı yaratmamak gibi ileri sürülen nedenleri kendini sunum taktikleri bağlamında düşünmek mümkündür.

Tıidenberg (2018) özçekimden nefret etme düşüncesinin altında, kollektif kültürel değerler ve sosyal normların belirleyici olduğunu söylemektedir. Nitekim çalışma içerisinde de saptanan toplumsal ahlaka aykırı bulma, kültürel ve dini nedenler alt temaları Türk toplumunun sahip olduğu kültürel yapıyı yansıtmaktadır. Sistemi eleştirdiği ve güvenmediği için özçekim paylaşımı yapmayanların bu düşüncelerinde dijital ortamın sunduğu olumsuzluklar bağlamında değerlendirmek gerekmektedir. Sosyal medyada yer verilen profil bilgi ve fotoğrafların diğer kullanıcılar tarafından, izinsiz bir şekilde farklı amaçlarla kullanıldığına dair çok çeşitli örneklerin geleksel ve yeni medyada yer alması ortama duyulan güvensizliği artırmaktadır. 
Kullanıcıların sanal ortama karşı güvensizlikleri ve dijital ortamda kayıt alınmaya karşı çekincelerinde kimlik hırsızlığı, açılan sahte hesaplara maruz kalma, şirketler ya da devletler tarafında gözetlenme korkusu yatabilmektedir.

Bunların yanısıra aile, arkadaş gibi yakın çevreleriyle bir araya geldiklerinde, yani grup halinde iken ya da sadece fotoğrafın içinde kendilerinin olmadığı halde güzel bir manzarayı göstermek amacıyla fotoğraf ekleyen kullanıcılar, çağın gerisinde kalmamak, kuşak çatışması yaşamamak adına da sınırlı sayıda paylaşımda bulunmaktadır. Aile ile yer verilen özçekim fotoğrafları "biz" olarak yer almanın, yani Türk toplumunun kollektivist doğası ile ilgilidir.

Sonuç olarak özçekim çağın yeni kendini sunum aracı olarak kendini kabul ettirmiştir. Daha iyi fotoğraf çeken akıllı telefonlar daha iyi filtre yapan uygulamalara olan talep git gite artmaktadır. Çalışmada özçekim paylaşımlarına karşı durulmamakta, bilinçli olarak yapılması gerektiğine inanılmaktadır.

\section{Kaynakça}

Akıner, N. ve Küngerü, A. (2015). Küresel Hegemonik İdeolojinin Popüler Tektipleştirme Pratiklerine Bir Örnek: Selfie. Akdeniz Üniversitesi İletişim Fakültesi Dergisi, 24, 132-147.

Alblooshi, A. (2015). Self-Esteem Levels \& Selfies: The Relationship Between SelfEsteem Levels and the Number of Selfies People Take and Post, and the Uses and Gratifications of Taking and Posting Selfies. Unpublished master's thesis. Middle Tennessee State University.

Alloway, T.P., Horton, J. Alloway, R.G. ve Dawson, C. (2013). Social networking sites and cognitive abilities: Do they make you smarter? Computers \& Education, $63,10-16$.

Barry, C. T., Doucette, H., Loflin, D. C., Rivera-Hudson, N. ve Herrington, L. L. (2015). 'Let Me Take a Selfie': Associations Between Self-Photography, Narcissism, and Self-Esteem. Psychology Of Popular Media Culture, doi:10.1037/ppm0000089.

Becker, J.A. ve Stamp, G.H. (2005). Impression Management in Chat Rooms: A Grounded Theory Model. Communication Studies, 56, 3.

Bennett, S. (2014, July 10). A brief history of the \#selfie (1839-2014). SocialTimes. Retrieved from http://www.adweek.com/socialtimes/first-ever-selfiehistory/499920

Burns, A. (2015). Self(ie)-Discipline: Social Regulation as Enacted Through the Discussion of Photographic Practice, International Journal of Communication 9, 1716-1733.

Cheung, C. M. Chiu, P. Y. ve Lee, M. K. (2011). Online socialnetworks: Why do students use facebook? Computers in Human Behavior, 27(4), 1337-1343.

Debord, G. (2016). Gösteri Toplumu. İstanbul:Ayrıntı Yayınları.

Fausing, B. (2013). Become an Image- On Selfies, Visuality and the Visual Turn in Social Medias https://www.zotero.org/groups/selfies_group/items/ itemKey/HD4VJGS. (erişim tarihi 5. 04. 2015). 
Fox, J. ve Rooney, M. C. (2015). The Dark triad and trait self-objectification as predictors of men's use and self-presentation behaviors on social networking sites. Personality and Individual Differences, 76, 161e165. http://dx.doi. org/10.1016/j.paid.2014.12.017.

Goffman, E. (2009). Günlük Yaşamda Benliğin Sunumu. (Çev. B. Cezar). İstanbul: Metis Yayıncllık Ltd.

Hofstede, G. (2001). Culture's Consequences: Comparing Values, Behaviors, Institutions, and Organizations Across Nations. Second Edition, Thousand Oaks CA: Sage Publications.

Hofstede, G. ve Minkov, M. (2010). Cultures and Organizations: Software of the Mind. Revised and Expanded 3rd Edition. McGraw-Hill 2010.

Kane, C.M. (2008). I'll u see you on myspace: Self-presentation in a social network website. Unpublished master's thesis. Cleveland State University.

Karasar, N. (1998). Bilimsel araştırma yöntemi. Ankara: Nobel Yayınları.

Katz, J.E. ve Crocker, E.T. (2015). Selfies and Photo Messaging as Visual Conversation: Reports from the United States, United Kingdom and China. International Journal of Communication 9, 1861-1872.

Leary, M. R. ve Kowalsky, R.M. (1990). Impression Management: A literature review and two-component model. Psychological Bulletin, 107(1), 34-37.

Leary, M.R. (1996). Self-presentation, impression management and interpersonal behaviour, Oxford: Westview Press.

Lobinger, K. ve Brantner, C. (2015) In the Eye of the Beholder: Subjective Views on the Authenticity of Selfies. International Journal of Communication 9, 18481860.

Martin, K.A., Leary, M.R. ve Rejeski, W.R. (2000). Self-presentational concerns in older adults for health and well-being. Basic and Applied SocialPsychology, 22(3), 169-179.

Mascheroni, G.,Vincent, J. ve Jimenez, E. (2015). Girls are addicted to likes so they post semi-naked selfies: Peer mediation, normativity and the construction of identity online. Cyberpsychology: Journal of Psychosocial Research on Cyberspace, 9(1), http://dx.doi.org/10.5817/CP2015-1-5.

Moreau, E. (2014). What is a selfie? Exploring the selfie trend. Retrieved from http:// webtrends.about.com/od/Mobile-Web-Beginner/a/What-Is-A-Selfie.htm

Oxford Dictionaries. (2015). Selfie (2nd ed.). Ulașllan uzantı http://www. oxforddictionaries.com/definition/english/selfie.

Peek, H. (2014). The selfie in the digital age: From social media to sexting. Cultural Psychiatry, 25. http://www.psychiatrictimes.com/cultural-psychiatry/selfiedigital-age-social-media-sexting (Erişim Tarihi: 01.06.2015).

Pempek, T.A., Yermolayeva, Y.A. ve Calvert, S.L. (2009) College Students' Social Networking Experiences on Facebook. Journal of Applied Developmental Psychology, 30, 227-238. http://dx.doi.org/10.1016/j.appdev.2008.12.010. 
Pösteki, N. ve Velioğlu, Ö. (2014). Bireyin Kendini Sunuş ve Konumlandırış Biçimindeki Dönüşüm: Selfie Kimlikler. I. Uluslararası İletişim Bilimleri ve Medya Araştırmaları Kongresi Bildiri Kitabı, I. Uluslararası İletişim Bilimleri ve Medya Araștırmaları Kongresi, Cilt 2.

Ramírez, B.G. ve Palu-ay, L. (2015). You Don't Look Like Your Profile Picture: The Ethical Implications of Researching Online Identities in Higher Education. Educational Research and Evaluation, 21 (2), 139-153.

Rosenfeld, P., Giacalone, R. A., \& Riordan, C. (1995). Impression management in organization.New York: Routhledge.

Rui, J.R. ve Stefanone, M.A. (2013). Strategic Image Management Online: Selfpresentation, Self-Esteem and Social Network Perspectives. Information, Communication \& Society, 16 (8), 1286-1305.

Shutz, A. (1998). Assertive, offensive, protective and defensive styles of selfpresentation: a taxonomy. The Journal of Psychology,132(6), 611-622.

Sorokowska A., Oleszkiewicz A., Frackowiak T., Pisanski K., Chmiel A. ve Sorokowski P. (2016). Selfies and personality: Who posts self-portrait photographs? Personality and Individual Differences, 90, 119-123.

Strauss, A. ve Corbin, J. (1990). Basics of Qualitative Research: Grounded Theory Procedures and Techniques. New Delhi: SAGE Publications.

Tiidenberg, K. (2018).Selfies. Why we love (and hate) them. https://www.academia. edu/36641813/SELFIES_Why_We_Love_and_Hate_Them

Wate, A. (2000). Impression management. http://www.i5ive.com/article.cfm/ social_psycology/53283(EriĢim tarihi:10.01.2010).

Weiser, E.B. (2015). \#Me: Narcissism and its facets as predictors of selfie-posting frequency. Personality and Individual Differences, 86, 477-481.

Wickel, T.M. (2015). Narcissism and Social Networking Sites: The Act of Taking Selfies. The Elon Journal of Undergraduate Research in Communications, 6 (1), $1-13$.

Williams, A.A. ve Marquez, B.A. (2015). The Lonely Selfie King: Selfies and the Conspicuous Prosumption of Gender and Race International. Journal of Communication 9, 1775-1787.

Yıldırım, A. ve Şimşek, H. (2003). Sosyal Bilimlerde Nitel Araştırma Yöntemleri. Ankara: Seçkin Yayınları.

Zanden, J. W. (1987). Social psychology (4th ed.). New York: McGraw-Hill. 
